\title{
Adam Lityński, Prawo Rosji i ZSRR 1917-1991, czyli historia wszechzwiązkowego komunistycznego prawa (bolszewików). Krótki kurs, 2. wydanie, Wydawnictwo C.H. Beck 2012, 402 strony
}

Dzieje Rosji radzieckiej i ZSRR budzą żywe zainteresowanie historyków, czego dowodem są liczne publikacje. Brakowało jednak do tej pory opracowania, które dawałoby pełny, wnikliwy wykład o przeobrażeniach prawa konstytucyjnego, karnego i cywilnego oraz ustroju sądów, prokuratury, adwokatury i organów bezpieczeństwa w latach 1917-1991. Książka Profesora Adama Lityńskiego znakomicie wypełniła tę lukę. Stanowi ona zarazem dopełnienie pionierskich dzieł Autora o prawie i ustroju Polski Ludowej (m.in. O prawie i sq̨dach początków Polski Ludowej, Białystok 1999; Historia ustroju i prawa Polski Ludowej - napisana wspólnie z Profesorem M. Kallasem, Warszawa 2000; Historia prawa Polski Ludowej, wydanie czwarte, Warszawa 2010). Przybliża bowiem poglądy i rozwiązania, które w dużej mierze wpłynęły na doktrynę oraz regulacje w zakresie ustroju politycznego i prawa sądowego w państwach będących po drugiej wojnie światowej w orbicie bezpośrednich wpływów ZSRR, w tym Polski.

Prezentowana książka jest nie tylko bardzo udaną syntezą ustaleń dotychczasowej literatury. W znacznej części odzwierciedla bowiem wyniki szeroko zakrojonych badań źródłowych Autora nad ustrojem i prawem Rosji radzieckiej i ZSRR. Rozmiary obszaru badawczego, poziom wnikliwości oraz dojrzałości analiz, refleksji i wniosków sprawiają, że praca A. Lityńskiego inspiruje i wielce ułatwia prowadzenie dalszych studiów.

W pracy wyodrębniono cztery rozdziały: I. Prawo konstytucyjne; II. Prawo karne; III. Prawo cywilne; IV. Sądy, adwokatura i organy ścigania. Poprzedza je Wprowadzeniesłowo o filozofii, państwie i prawie.

W rozdziale I (najobszerniejszym, liczącym blisko 100 stron) Autor daje wykład o przeobrażeniach ustroju politycznego państwa radzieckiego. $Z$ wielkim znawstwem przybliża okoliczności powstawania, systematykę i najistotniejsze postanowienia kolejnych konstytucji i aktów prawnych okołokonstytucyjnych (wytykając jednocześnie najważniejsze w nich luki). Zarazem dokładnie konfrontuje owe regulacje praktyką konstytucyjną. Z niezwykłą precyzją wykazuje ich fasadowy na ogół charakter, odsłaniając pozakonstytucyjne struktury i mechanizmy faktycznej władzy.

Przykładowo, analizując rozwiązania konstytucji z 1918 r., Autor wykazuje w szczególności, że: 1) wybory nie były ani powszechne, ani równe, ani bezpośrednie (poza wyborami do organów najniższego szczebla), a tym bardziej proporcjonalne, bo nie istniały konkurujące ze sobą listy partyjne; nie zapewniono też tajności głosowania; 2) powtórzono za dekretem Wszechrosyjskiego Centralnego Komitetu Wykonawczego z 28 stycznia 1918 r., iż państwo jest federacją republik narodowych, co było fikcją aż do 20 grudnia 1922 r.; 3) nie określono liczby członków Zjazdu Rad, nie oznaczono też długości jego sesji; 4) Wszechrosyjski Centralny Komitet Wykonawczy był „całkowicie odpowiedzialny” przed Zjazdem Rad, ale nie określono zakresu, form i procedury owej odpowiedzialności. Jego kompetencje sprawiły, iż w istocie był ważniejszy aniżeli Zjazd Rad; 6) nie skonkretyzowano „całkowitej odpowiedzialności” komisarzy ludowych przed Radą Komisarzy Ludowych oraz jej „całkowitej odpowiedzialności” przed Zjazdem 
Rad oraz Wszechrosyjskim Centralnym Komitetem Wykonawczym; 7) nie ustanowiono żadnych organów dla rozstrzygania sporów kompetencyjnych ani specjalnych trybunałów orzekających w przypadku naruszenia prawa podczas urzędowania; 8) Zjazd Rad, Wszechrosyjski Centralny Komitet Wykonawczy Rad, jak i Rada Komisarzy Ludowych były wyposażone w kompetencje zarówno ustawodawcze, jak i wykonawcze oraz kontrolne, co odzwierciedlać miało programowe odrzucenie nie tylko teorii podziału władzy, ale również zasady ścisłego podziału kompetencji, i prowadziło do pełnego chaosu ustawodawczego; 9) konstytucja nie wskazała, kto sprawuje funkcję głowy państwa; 10) nie przeprowadzono rozróżnienia między ustawą zasadniczą a zwykłą; nie było specjalnego trybu zmiany konstytucji; 11) całkowicie pominięto w konstytucji struktury oraz wszelkie inne zagadnienia organów ścigania i wymiaru sprawiedliwości; 12) konstytucja nie regulowała również kompetencji wielu innych organów, z Nadzwyczajną Komisją do Walki z Kontrrewolucją i Sabotażem na czele, która zwłaszcza w okresie wojny domowej odgrywała pierwszoplanową rolę w totalitarnym systemie władzy; 13) hierarchiczna struktura rad pozwalała na realizację zasady centralizmu demokratycznego, który $\mathrm{w}$ istocie był zaprzeczeniem jakiegokolwiek demokratyzmu i samorządu; 14) jedynie daleko idącym kamuflażem było pominięcie w konstytucji roli partii bolszewickiej w życiu publicznym. W rzeczywistości niemal wszystkie decyzje podejmowano w zbiurokratyzowanym aparacie partyjnym i przekazywano je do wykonania władzom państwowym. W ważniejszych sprawach aparat partyjny sprawował bezpośrednio funkcje kierowania i zarządzania, co prowadziło do dublowania dwóch aparatów biurokratycznych: partyjnego i państwowego. Aparat państwowy stanowił tyko „zewnętrzny szyld kamuflujący oraz miał charakter wykonawczy w stosunku do decyzji partyjnych". Zamiast dyktatury proletariatu skonstruowano system „dyktatury partii bolszewickiej”, ze szczególną rolą partyjnego aparatu biurokratycznego". Warto w tym miejscu zauważyć, że kierownicza rola partii komunistycznej została wyeksponowana w konstytucji ZSRR z 1977 r., która głosiła, iż wytycza ona „generalne perspektywy rozwoju społeczeństwa, linię polityki wewnętrznej i zagranicznej ZSRR”, kontynuując tym samym dublowanie struktur władzy państwowej i aparatu partyjnego.

To, przykładowe tylko, zasygnalizowanie uwag i ustaleń zaprezentowanych w książce A. Lityńskiego, z których każda jest rzetelnie udokumentowana i uzasadniona, odnoszących się do ustroju politycznego Rosji na gruncie Konstytucji z 1918 r., ma stanowić dla czytelnika zapowiedź stopnia wnikliwości i kompleksowości ujęcia tej problematyki, także w okresach obowiązywania następnych konstytucji (z 1924, 1936,1977 r.) aż do upadku ZSRR i powołania Wspólnoty Niepodległych Państw.

Wyodrębniony rozdział o prawach i obowiązkach obywateli pojawił się po raz pierwszy w dziejach radzieckiego konstytucjonalizmu w ustawie zasadniczej z $1936 \mathrm{r}$. Autor dobitnie podkreśla, że konstytucyjne regulacje o prawach obywateli i rzeczywistość w tym przedmiocie „dawały najbardziej drastyczną rozbieżność między prawdą a fałszem”. Wydaje się, że warto byłoby pokazać w tym miejscu zwłaszcza rzeczywistą sytuację wspólnot religijnych, a przede wszystkim prawosławnych. Czasy Rosji radzieckiej i ZSRR aż do końca lat osiemdziesiątych, to przecież okres brutalnych ograniczeń w możliwościach zaspokajania potrzeb religijnych; prześladowań i inwigilacji Cerkwi oraz prób rozbijania jej od wewnątrz. Katechizacja traktowana była jak czyn kryminalny. Rolę Cerkwi sprowadzono do wąsko rozumianych ram kultowych. Całkowicie podporządkowana państwu, obłożona wyjątkowo wysokimi podatkami, pozbawiona osobo- 
wości prawnej, utraciła możliwości oddziaływania na społeczeństwo. Pełną kontrolę nad wiernymi powierzono organom uzależnionym od KGB. Drastycznie zredukowano liczbę świątyń i seminariów duchownych ${ }^{1}$. Jak pisze J. Smaga, „Przez ponad 70 lat było to państwo wyznaniowe, w którym do rangi religii państwowej podniesiony został wojujący ateizm, praktykowany przez sektę będących u władzy komunistów"2.

W rozdziale II omówione zostały przeobrażenia prawa karnego materialnego i procedury karnej. Problematyka ta pozostaje w bardzo ścisłym związku z zagadnieniami ustroju politycznego, będącymi przedmiotem rozważań w rozdziale I. Charakter ustroju politycznego można bowiem łatwo ustalić analizując dobra i wartości, które objęte są ochroną prawnokarną. Wyznacznikiem charakteru ustroju politycznego jest także stosunek władzy państwowej do praw jednostki. Prawo karne, będąc dziedziną, która swoimi sankcjami w sposób najbardziej drastyczny wkracza w prawa jednostki, wyraźnie uwidacznia zarazem stosunek władzy państwowej do praw jednostki. Prawo karne jest zatem „stosunkowo wiernym zwierciadłem ustroju, który ma zabezpieczać” i wykazuje cechy narzucone mu przez ten ustrój ${ }^{3}$.

Przeobrażenia prawa karnego materialnego ujęte zostały (na blisko 60 stronach) w 4 punktach, wyodrębnionych w porządku chronologicznym: „I. 1917-1921”, „II. NEP i Kodeks z 1922 r.”, „III. 1924-1953 - od śmierci Lenina do śmierci Stalina”, „IV. Demontaż stalinowskiego prawa karnego”. Autor dogłębnie wyjaśnia funkcje prawa karnego, zasady odpowiedzialności karnej, podstawy wymiaru kary. Daje również przegląd części szczegółowej kolejnych kodeksów, eksponując znamiona przestępstw, które ówczesne władze uznały za najgroźniejsze, i odsłaniając dobra i wartości doznające szczególnej ochrony prawnokarnej.

Autor rozpoczyna swe rozważania od stwierdzenia, iż w systemie prawa radzieckiego (aż do 1991 r.) prawo karne odgrywało rolę zdecydowanie najważniejszą. Było bowiem instrumentem walki klasowej, narzędziem sprawowania władzy. Nowa władza radziecka zerwała i odrzuciła dotychczasowy system prawa karnego, wykazując postawę nihilizmu prawnego. Dobitnie wyraża ją, cytowany przez Autora, fragment Przewodnich zasad prawa karnego RFSRR z 12 grudnia 1919 r., które były pierwszym aktem prawa karnego, o ambicjach kompleksowej regulacji zasad wymiaru rewolucyjnej sprawiedliwości (w latach 1917-1918 poprzedził je szereg aktów politycznych i prawnych, w których pojawiały się przepisy karne materialne lub procesowe). Czytamy tam m.in., iż „Proletariat, zdobywszy w rewolucji październikowej władzę, złamał burżuazyjny aparat państwowy służący uciskowi mas pracujących, ze wszystkimi jego instytucjami, armią, policją, sądami i cerkwią. Zrozumiałe, że ten sam los musiał spotkać także wszystkie burżuazyjne kodeksy, całe burżuazyjne prawo [...którego proletariat] nie mógł przysposobić dla swoich celów i burżuazyjne kodeksy przeszłej epoki musiał odłożyć do archiwum historii. Bez specjalnych reguł, bez kodeksów, uzbrojony lud poradził sobie i radzi sobie ze swoimi ciemięzcami”. Pierwszy kodeks karny RFSRR został uchwalony w 1922 r.

Podsumowując swe rozważania o prawie karnym materialnym okresu komunizmu wojennego i początków NEP, A. Lityński bardzo trafnie eksponuje jego cechy. Podkreśla w szczególności, iż „spełniało zdecydowanie funkcję ochronną i tej funkcji podporząd-

J. Smaga, Narodziny i upadek imperium. ZSRR 1917-1991, Kraków 1992, s. 226-227.

Ibidem, s. 368.

A. Zoll, Prawo karne w systemie totalitarnym, „Znak” 1992, nr 11, s. 111. 
kowywało wszelkie rozwiązania szczegółowe; w konsekwencji odrzucało wszelkie samoograniczenia typu gwarancyjnego", polegające na stworzeniu barier ograniczających władzę w korzystaniu z sankcji i innych środków przymusu wobec społeczeństwa. Zachodzi bowiem sprzeczność pomiędzy założeniami systemu totalitarnego a akceptowaniem funkcji gwarancyjnej prawa karnego, zakładającej, że jednostka korzysta z wolności i praw, które władza musi respektować. Wolności i prawa jednostki w systemie totalitarnym były „aktem łaski ze strony władzy i pozostawały w jej całkowitej dyspozycji”4. Odpowiedzialność oparto najpierw na szeroko pojmowanej analogii iuris, a od kodeksu z 1922 r. - na analogii legis, jak również na „czynniku świadomości rewolucyjnej”, przy ignorowaniu reguły nullum crimen sine lege. Autor wskazuje również na relatywizowanie odpowiedzialności ze względu na osobę sprawcy (element klasowy) oraz dopatrywanie się wszędzie, nawet w drobnej przestępczości kryminalnej, aspektów politycznych.

W związku z tym, że konstytucja ZSRR z 1924 r. przekazała do kompetencji federacji ustanawianie podstaw ustawodawstwa cywilnego i karnego ZSRR, w dniu 31 października 1924 r. wydano Zasady przewodnie ustawodawstwa karnego ZSRR i republik związkowych, stanowiące zarys części ogólnej kodeksu karnego. Na ich podstawie każda z republik związkowych przystąpiła do opracowania własnego kodeksu karnego. Na wstępie wnikliwej charakterystyki wydanego w 1926 r. kodeksu karnego SFRR Autor wyjaśnia, iż tylko pozornie opierał się on na ideologii ochronnej, zaczerpniętej z pozytywistycznej szkoły włoskiej nurtu socjologicznego w prawie karnym, w myśl której ważniejsze od wagi samego przestępstwa i stopnia zawinienia była osoba sprawcy i stan zagrożenia dla porządku społecznego, jaki ona stwarzała. Stosownie do tego zagrożenia należało zastosować środki ochrony społecznej. Autor podkreśla, że w systemach liberalnych można było je stosować jedynie wobec osoby, która dopuściła się czynu zabronionego pod groźbą kary. W systemach totalitarnych wykorzystywano owe rozwiązania, by stosować środki zabezpieczające (ochronne) predeliktalnie, tzn. zanim zostało popełnione przestępstwo, wobec osób, które żadnego przestępstwa nie popełniły. Stąd, jak ocenia A. Lityński, w kodeksie karnym z 1926 r. naśladownictwo rozwiązań nurtu socjologicznego miało „charakter zewnętrzny i w znacznym stopniu ograniczało się do przejętej terminologii”. Jako jedyne zadanie prawa karnego kodeks karny z 1926 r. wskazywał ochronę ustroju (państwa) przed „społecznie niebezpiecznymi czynami” drogą stosowania środków ochrony społecznej. Dobitnie wynikało to z cytowanego przez Autora art. 1: „Ustawodawstwo karne RFSRR ma za zadanie ochronę socjalistycznego ustroju państwa robotników i włościan oraz zaprowadzonego w nim porządku prawnego przed społecznie niebezpiecznymi czynami (przestępstwami) drogą stosowania do osób, które je popełniają środków ochrony społecznej w niniejszym kodeksie wskazanych". W części szczegółowej na czoło wysunięte więc były, analogicznie jak w kodeksie z 1922 r., przestępstwa kontrrewolucyjne (ujęte aż w czternastu obszernych artykułach), oraz „szczególnie niebezpieczne dla ZSRR” przestępstwa przeciwko władzy.

Kodeks podtrzymał konstrukcję materialnej definicji przestępstwa i zasadę analogii legis. W czasach stalinowskich wydano szereg dekretów, rozszerzając zakres kodeksowej penalizacji, znacznie pogłębiających represyjność prawa karnego. Autor dokonał przeglądu tych regulacji, eksponując szczególnie osławioną lex Kirow (obowiązującą do 
1956 r.), która drastycznie zaostrzyła odpowiedzialność i zlikwidowała wszelkie gwarancje procesowe oskarżonego w sprawach politycznych. Charakterystykę owych regulacji dopełniają wymownie dane liczbowe, ilustrujące tragiczne skutki ich praktycznego stosowania.

Przełom w systemie prawa karnego ZSRR nastąpił w latach 1958-1961. Autor podkreśla, iż po raz pierwszy od 1917 r. nawiązało ono wtedy do standardów europejskich, wspierając się na podstawach legalistycznych i zbliżając do rozwiązań neoklasycznych. Podstawy ustawodawstwa karnego ZSRR i republik związkowych z 1958 r., jak i kodeks karny RFSRR z 1960 r. dość tradycyjnie, ale bardziej kompleksowo ujmowały zadania prawa karnego: „ochrona przed zamachami przestępnymi radzieckiego ustroju społecznego i państwowego, własności socjalistycznej, jednostki i praw obywateli oraz całego socjalistycznego porządku prawnego"(art. 1). Autor podkreśla, iż w dalszej części art. 1 ustanowiono zasady nullum crimen, nulla poena sine lege, wykluczając tym samym obowiązującą dotąd analogię, a w art. 6 zawarta została zasada lex retro non agit. W 1977 r. owe zasady trafiły do konstytucji ZSRR. Definicja przestępstwa łączyła w sobie elementy definicji materialnej i formalnej, a podstawą odpowiedzialności karnej stała się wina.

Ustawodawstwo karne $\mathrm{z}$ lat 1958-1961 było poddawane w następnych latach licznym nowelizacjom, oznaczającym nawrót do surowej polityki kryminalnej ${ }^{5}$ i karania w trybie administracyjnym, zaostrzającym system represji karnej, ale - jak podkreśla Autor - „do czasów stalinowskich powrotu nie było”. W szczególności, aż do połowy lat osiemdziesiątych, na szeroką skalę pozbawiano wolności osoby zaliczone do opozycji politycznej, poprzez zamykanie ich w specjalnych szpitalach dla psychicznie chorych (znajdujących się w gestii KGB i MSW), poddając ich zabiegom farmakologicznym, ze stosowaniem łamiących wolę środków psychotropowych włącznie. Zaniżano w ten sposób liczbę więźniów politycznych, dyskredytując zarazem program i żądania dysydentów, u których „rozpoznano” chorobę psychiczną. Usłużni psychiatrzy dokonali odkrycia nowej jednostki chorobowej, na którą mieli zapadać ludzie krytycznie nastawieni wobec panującego systemu. Najczęściej była to „schizofrenia pełzająca” lub „schizofrenia bezobjawowa”, którą miały znamionować m.in. „szkalowanie otoczenia” oraz „obłęd reformatorski”6. W 1988 r., gdy szpitale psychiatryczne wyłączono spod gestii KGB, około 2 milionów osób „hospitalizowanych” nagle „ozdrowiało”7.

W dalszej części rozdziału II Autor charakteryzuje - w porządku chronologicznym - źródła określające procedurę karną. Przybliża i analizuje w szczególności postanowienia: kolejnych dekretów (nr 1, 2 i 3) o sądzie, odnoszących się do sądów ludowych, które zastąpiła (podsumowując i podtrzymując dotychczasowe rozwiązania) ustawa z 1918 r. o sądzie ludowym; ustaw (z 1918 i 1919 r.) o trybunałach rewolucyjnych; kodeksów postępowania karnego RFSRR z 1922 (w redakcji z 1923) i 1960 r. Wyjaśniając cechy i zasady procedury karnej czasach stalinizmu Autor wyraźnie zastrzega wpierw, iż istniała ona „tylko na papierze i na papierze prezentowała się zupełnie przyzwoicie”, a od rzeczywistości dzieliła ją „przepaść”. Mianem „papierowych deklaracji” określa przepisy konstytucji z 1936 r. o niezawisłości sędziowskiej, o jawności rozprawy sądowej, o prawie oskarżonego do obrony, o języku narodowym w postępowaniu sądowym,

5 W latach 1960-1974 zmieniono ponad sto norm. Dwie trzecie owych nowelizacji zaostrzało system represji karnej, A. Dziadzio, Powszechna historia prawa, Warszawa 2008, s. 274. 
o nietykalności osobistej („Nikt nie może być aresztowany bez postanowienia sądu lub bez sankcji prokuratora”), o nietykalności mieszkań oraz tajemnicy korespondencji.

Dowiadujemy się również o zmianach procedury karnej w sprawach dotyczących „organizacji terrorystycznych i aktów terroru” (lex Kirow z 1934 r.) oraz w sprawach o kontrrewolucyjne szkodnictwo i dywersję (w 1937 r.). W szczególności, według lex Kirow: śledztwo było skrócone do $10 \mathrm{dni}$; akt oskarżenia doręczano oskarżonemu na jedną dobę przed rozpoczęciem rozprawy; dopuszczalne było orzekanie zaoczne (nawet jeśli oskarżony znajdował się w rękach organów ścigania); udział oskarżenia oraz obrony w sądzie był niedopuszczalny; postępowanie było jednoinstancyjne (kasacja była niedopuszczalna); nie przysługiwało prawo łaski; NKWD miało wykonać wyrok w ciągu 24 godzin.

Charakteryzując k.p.k. RFSRR z 1960 r. Autor pisze w szczególności, iż w generaliach podtrzymał on dotychczasowe rozwiązania. Wskazuje zarazem przepisy zmierzające do przestrzegania praworządności (o nietykalności osobistej, nietykalności mieszkania, tajemnicy korespondencji, równości obywateli wobec prawa i sądu, niezawisłości sędziów i podporządkowaniu ich tylko ustawom) oraz zmniejszające represyjność systemu karnego (kilka przepisów o możliwości umorzenia postępowania). Dostrzega również wyraźną reakcję na dotychczasową praktykę śledczą i „sądzenie” przez organy bezpieczeństwa. Postanowiono bowiem, iż tryb postępowania przewidziany w k.p.k. jest jedynym dopuszczalnym przed wszystkimi sądami, organami prokuratury, śledztwa i dochodzenia. Tę zasadę wzmacniały art. 4 („Nikt nie może być pociągnięty do odpowiedzialności w charakterze oskarżonego $\mathrm{w}$ inny sposób niż na podstawach i w trybie przewidzianych w ustawie”) i art. 13 („Wymiar sprawiedliwości w sprawach karnych sprawuje wyłącznie sąd. Nikt nie może być uznany za winnego popełnienia przestępstwa i skazany w inny sposób niż na mocy wyroku sądu”). Kodeks postępowania karnego RFSRR z 1960 r. normował również postępowanie dotyczące zastosowania środków przymusowych o charakterze leczniczym. Cytując owe regulacje Autor kolejny raz przestrzega, iż „trzeba odróżniać papierowy przepis od rzeczywistości (...). Wobec fikcji niezawisłości sędziowskiej i niezależności organów całego postępowania karnego, elementy praworządności mogły być przestrzegane o tyle tylko i na tyle tylko, na ile życzyły sobie tego władze polityczne - partia komunistyczna”.

W rozdziale III Autor analizuje prawo cywilne materialne (źródła, część ogólna, prawo rzeczowe, prawo zobowiązań, prawo spadkowe), prawo rodzinne oraz postępowanie cywilne. Jak widać, nie podtrzymano pandektowej tradycji cywilistycznej i prawo rodzinne nie stanowiło integralnej części prawa cywilnego.

W bolszewickiej Rosji i ZSRR cywilistyka „Zwiędła”. Do lata 1918 r. praktycznie całe przedrewolucyjne prawo cywilne przestało istnieć. Konfiskata bez odszkodowania całej wielkiej własności ziemskiej i likwidacja prywatnej własności ziemi (najgruntowniejsze jak podkreśla Autor - wywłaszczenie w dziejach świata) oznaczały zarazem, w tym rolniczym kraju, obalenie fundamentów społecznych (nabywcy ziemi byli od tej pory jedynie jej użytkownikami). Całkowicie zmieniono również stosunki obligacyjne, zlikwidowano prawo spadkowe, stworzono zupełnie nowe prawo rodzinne odwzorowujące zasady skrajnie odmienne od dotychczasowych. Autor już na wstępie swych rozważań stawia

6 J. Smaga, op. cit., s. 256-257.

7 M. Klementowski, Powszechna historia ustroju, Warszawa 2012, s. 601. 
bardzo interesującą, ważną i oryginalną tezę, iż „prawo cywilne w systemie radzieckim niezwłocznie stało się prawem publicznym. To absolutna nowość w światowych dziejach prawa”. O przesunięciu prawa cywilnego do sfery publicznej zadecydowała powstała w tym czasie baza własności, określana później jako socjalistyczna, oraz socjalistyczne metody regulacji jej funkcjonowania: centralizm, akty administracyjne, reglamentacja i rozdzielnictwo. W dalszych rozważaniach analizujących kolejne akty prawne kształtujące nowe prawo cywilne Autor bardzo rzetelnie uzasadnia i dokumentuje swój pogląd.

Zauważmy, że w Rosji, w związku z zanikiem własności prywatnej (przejściowo tylko była odbudowana w latach NEP, ale została rychło zlikwidowana wraz z porzuceniem tej polityki) tolerowano tylko własność osobistą. Obejmowała ona wpierw jedynie drobne przedmioty codziennego użytku. Według kodeksu cywilnego RFSRR z 1964 r. dotyczyła mienia zgromadzonego ze środków pochodzących wyłącznie z pracy - np. mieszkanie do 60 m kw. (prywatną własność w Rosji przyjęła dopiero konstytucja z 1993 r., a prywatny obrót ziemią stał się możliwy od 2002 r. ${ }^{8}$ ). Prawo spadkowe miało zatem bardzo ograniczony zasięg, a nadto, w latach 1926-1943 obowiązywał progresywny podatek spadkowy, sięgający do 90\% wartości spadku. Rozwiązania odpowiadające standardom europejskim pojawiły się dopiero w przyjętych w $1961 \mathrm{r}$. Zasadach ustawodawstwa cywilnego ZSRR i republik związkowych oraz w uchwalonym w 1964 r. Kodeksie cywilnym RFSRR.

Kolejny paragraf rozdziału III rozpoczyna zwięzły przegląd poglądów przedstawicieli doktryny marksistowskiej na małżeństwo i rodzinę, które legły u podstaw niezwykle oryginalnych i szkodliwych rozwiązań radzieckiego prawa rodzinnego. Szczególnie wyróżniały się tu regulacje ustanawiające bardzo liberalne podejście do rozwodów. Dekret z 31 listopada (19 grudnia) 1917 r. przewidywał dwojaki tryb postępowania prowadzącego do rozwiązania małżeństwa. Na zgodny wniosek stron rozwód następował przez zarejestrowanie tego faktu w urzędzie stanu cywilnego. W razie sporu stron rozwiązania małżeństwa dokonywał sąd, ale nie kontrolował on zasadności wniosku rozwodowego. Po wejściu w życie k.p.c. z 1923 r. postępowanie rozwodowe traktowane było jako niesporne. Kodeks rodzinny z 1926 r. przewidywał rozwiązanie małżeństwa wyłącznie w trybie administracyjnym, w drodze jednostronnego (nawet nieumotywowanego) oświadczenia małżonka, co Autor celnie określa jako quasi-wypowiedzenie umowy małżeńskiej w urzędzie stanu cywilnego. Drugi małżonek nie korzystał z żadnej ochrony. Nie był nawet wzywany do urzędu stanu cywilnego. Otrzymywał jedynie zawiadomienie o rozwiązaniu małżeństwa. Ustanie małżeństwa następowało $\mathrm{z}$ chwilą stosownego wpisu w aktach stanu cywilnego. W 1944 r. wprowadzono wyłącznie sądowy tryb rozwiązania małżeństwa (poprzedzony postępowaniem pojednawczym przed sądem ludowym). Niedopuszczalny był już wniosek bez uzasadnienia. Konieczne było podanie powodów żądania rozwodu, a sąd mógł wniosek oddalić. Rozluźnienie owych rygorów nastąpiło w następstwie przyjęcia w 1968 r. Zasad ustawodawstwa ZSRR i republik związkowych o małżeństwie i rodzinie. Rozwiązanie małżeństwa następowało przez orzeczenie urzędu stanu cywilnego albo sądu. Tryb administracyjny był właściwy w szczególności w przypadku zgodnego oświadczenia stron, gdy małżonkowie nie mieli małoletnich dzieci. W razie sporu między małżonkami o rozwodzie decydował sąd. Następstwa

8 A. Dziadzio, op. cit., s. 272. 
owego, liberalnego podejścia do rozwodów, ilustrują bardzo wymownie dane liczbowe przytoczone przez Autora. Wskaźnik rozwodów przypadających na 1000 mieszkańców $(3,4)$ plasował ZSRR w połowie lat osiemdziesiątych na pierwszym miejscu w kręgu krajów tzw. socjalistycznych. W 1985 r. w ZSRR zarejestrowano 933100 rozwodów.

Omawianie postępowania cywilnego Autor zaczyna od słynnych trzech dekretów o sądzie z 1917 r. Przypomina, że dekret nr 1 nie określał nowych procedur sądowych, stanowiąc, iż sądy lokalne mogą orzekać na mocy ustaw dawnych, „o ile takowe nie zostały zmienione przez rewolucję i nie sprzeciwiają się rewolucyjnemu sumieniu i rewolucyjnej świadomości prawnej”. Dekret nr 2 był już próbą uregulowania postępowania sądowego, zarówno karnego, jak i cywilnego, z naciskiem - co zrozumiałe - na prawo karne. Podtrzymano możliwość orzekania według zasad procedur z 1864 r., o ile nie zostały uchylone dekretami nowej władzy i nie sprzeciwiały się „świadomości prawnej klas pracujących”. Procedura cywilna z 1864 r. oparta była na zasadach: kontradyktoryjności, ustności, swobodnej oceny dowodów. Autor przypomina również, iż przewidywała ona możliwość tworzenia przez sąd zasad prawa poprzez orzekanie zgodnie $\mathrm{z}$ „duchem prawa”. Charakteryzując postępowanie cywilne według dekretu nr 2, Autor celnie zauważa, iż zmiany w stosunku do ustawy o postępowaniu cywilnym z $1864 \mathrm{r}$. poszły w kierunku rozluźnienia form postępowania. Z kolei w dekrecie nr 3 uregulowano w zakresie procedury cywilnej jedynie drobną kwestię właściwości sądu.

Charakteryzując kodeks postępowania cywilnego z 1923 r., Autor zauważa m.in., iż nie było w nim odwołania do „rewolucyjnej świadomości prawnej”. Od sędziów oczekiwano jednak rozpatrywania spraw i orzekania w duchu rewolucyjnym, przewidując (art. 4), że w razie luki w prawie sędzia sam ma stworzyć zasadę prawną, którą uważa za słuszną, z uwzględnieniem intencji rządu bolszewickiego. Autor podkreśla, że podstawowymi zasadami k.p.c. z 1923 r. były: równość stron, ustność, jawność, bezpośredniość oraz szczególnie mocno zaakcentowana instrukcyjność, zakładająca bardzo aktywną rolę sądu w procesie. Autor zwraca uwagę również na poważne ograniczenie zasad: kontradyktoryjności (poprzez ingerencje sądu w postępowanie dowodowe) oraz dyspozycyjności (sąd nie był związany zawartymi w pozwie granicami żądania i mógł zasądzić ponad żądanie, jeżeli było to uzasadnione interesem państwa lub obywatela). W ten sposób realizowano zasadę prawdy obiektywnej, która przetrwała do końca 1995 r. Autor podkreśla również, iż k.p.c. z 1923 r. dawał prokuratorowi możliwość włączenia się w każdym stadium do każdego postępowania cywilnego; co więcej, mógł samodzielnie wnieść pozew, i to nawet wbrew woli strony, gdy uznał, że wymaga tego dobro państwa radzieckiego albo interes klasy robotniczej. Autor zauważa, iż w czasach stalinowskich k.p.c. z 1923 r. nie cieszył się dobrą opinią w politycznym kierownictwie totalitarnego państwa oraz u reżimowych prawników, „co dobrze świadczy o treściach kodeksu”.

Charakteryzując k.p.c. RFSRR z 1964 r., Autor pisze, iż powtórzył on wszystkie przepisy Zasad postępowania cywilnego ZSRR i republik związkowych, uchwalonych przez Radę Najwyższą ZSRR w 1961 r. Podkreśla, iż zasadami nowej procedury cywilnej były: jawność, bezpośredniość, ciągłość, ustność, szybkość. Podtrzymano rozwiązanie, że sąd nie jest związany wnioskami stron ani granicami pozwu, oraz może gromadzić materiał dowodowy z własnej inicjatywy. Dowody oceniał według swobodnego uznania, kierując się „socjalistyczną praworządnością”. Podobnie jak do tej pory istniała szeroka możliwość udziału prokuratora na każdym etapie i w każdej sprawie, gdy uznał on, że wymaga 
tego interes społeczny. Nowością było unormowanie rozpatrywania w postępowaniu cywilnym sporów między organami administracji a obywatelami.

W rozdziale IV Autor daje wykład o przeobrażeniach usytuowania ustrojowego, zadaniach i roli sądów, prokuratury, adwokatury i organów bezpieczeństwa, który dopełnia rozważaniami na temat systemu obozów pracy przymusowej. Na wstępie stwierdza m.in., iż w następstwie odrzucenia przez nową władzę zasady trójpodziału władz, sądy nie mogły być traktowane jako władza odrębna, a tym bardziej niezależna od władz ustawodawczej i wykonawczej. Autor analizuje występujące wpierw równolegle dwie struktury sądów: sądy ludowe oraz trybunały rewolucyjne („doraźne sądy powszechne”). Obok nich funkcjonowały jeszcze sądy wojskowe oraz administracyjny tryb orzekania kar.

Trybunały rewolucyjne (czynne niemal do końca 1922 r.) miały orzekać w sprawach o przestępstwa kontrrewolucyjne, spekulację, naruszenie dekretów władzy radzieckiej, nadużycie stanowiska służbowego oraz antyludowe przestępstwa prasowe. Orzeczenia miały ferować (w myśl instrukcji Ludowego Komisariatu Sprawiedliwości) „kierując się okolicznościami sprawy i rewolucyjnym sumieniem”. Autor zauważa, że w okresie największego terroru stalinowskiego szczególną rolę odegrało Kolegium Wojskowe SN ZSRR, realizując politykę czystek w aparacie partyjnym (słynne "procesy moskiewskie”). Sądziło ono także w sprawach mniej głośnych. Autor przytacza fragment meldunku przewodniczącego Kolegium Wojskowego SN ZSRR, z którego wynika, iż w latach 1936-1938, pracując na sesjach miejscowych oraz wyjazdowych aż w 60 miastach, orzekło ono 30514 kar śmierci i 5643 kary więzienia. Autor skrupulatnie obliczył, że na jednego oskarżonego nie mogło zatem przypadać więcej niż około 15 minut.

Omawiając ustrój sądów powszechnych na gruncie ustawy z 1922 r. Autor czyni na końcu swych rozważań wielce wymowną uwagę, iż wszystkie one sądziły jedynie część spraw i tylko drobniejsze kryminalne („orzekały jak gdyby w odniesieniu do wierzchołka góry lodowej”). Podkreśla wyraźnie, iż „Znaczna część wielomilionowej populacji łagrów i więzień nigdy sali sądowej nie oglądała, nawet symbolicznie przez kwadrans. Skazywani byli w trybie zaocznym i nie przez sąd, ale przez organ administracyjny, jakim było ciało wyłaniane przez organa bezpieczeństwa”. W dalszym ciągu swych rozważań Autor dokumentuje tę tezę analizując, w ujęciu chronologicznym, przeobrażenia struktur (wraz z obsadą stanowisk kierowniczych) i trybu działania organów bezpieczeństwa oraz podając przerażające dane liczbowe, ilustrujące skalę dokonanych przezeń mordów i prześladowań.

Książka Profesora A. Lityńskiego jest dziełem wybitnym. Bardzo znacząco wzbogaca dorobek dotychczasowych badań przeobrażeń ustroju politycznego, prawa cywilnego, prawa karnego, struktury i trybu funkcjonowania sądów, prokuratury, adwokatury oraz organów bezpieczeństwa porewolucyjnej Rosji i Związku Radzieckiego. Kolejne fazy rozwoju prawa radzieckiego ukazane są $\mathrm{w}$ powiązaniu $\mathrm{z}$ ich uwarunkowaniami o charakterze doktrynalnym, ideologicznym oraz społeczno-gospodarczym. Przepełnione głęboką refleksją historycznoprawną dzieło Profesora A. Lityńskiego pokazuje zarazem tragiczne skutki tworzenia i stosowania prawa w oderwaniu od tradycji, wyrażając tym samym wielką przestrogę przed odrzucaniem uniwersalnych, nieprzemijających wartości myśli jurydycznej, które zawsze powinny wypełniać rdzeń obowiązującego porządku prawnego i fundamenty konstytucyjne państwa. Warto zatem podjąć starania, aby na szeroką skalę pojawiło się w obiegu naukowym także poza Polską. 
Wykorzystując niezwykle rozległy zestaw literatury i materiałów źródłowych Autor potrafił uwypuklić sprawy najważniejsze, na których ogniskuje uwagę czytelnika poprzez ciekawą narrację, zbudowaną klarownym, wręcz finezyjnym językiem. Poprzedzające zasadnicze rozdziały Wprowadzenie - słowo o filozofii, państwie i prawie oraz liczne wyjaśnienia, zamieszczone w rozbudowanych przypisach, czynią książkę Profesora A. Lityńskiego przystępną nie tylko dla specjalistów. Winna być zatem lekturą obowiązkową dla bardzo szerokiego kręgu czytelników. 